\title{
Performance of an automatically controlled wood stove: Thermal efficiency and carbon monoxide emissions
}

Illerup, Jytte Boll; Hansen, Brian Brun; Lin, Weigang; Nickelsen, Joachim; Pedersen, Vagn Hvam; Eskerod, Bente; Dam-Johansen, Kim

Published in:

Renewable Energy

Link to article, DOI:

10.1016/j.renene.2019.11.057

Publication date:

2020

Document Version

Peer reviewed version

Link back to DTU Orbit

Citation $(A P A)$ :

Illerup, J. B., Hansen, B. B., Lin, W., Nickelsen, J., Pedersen, V. H., Eskerod, B., \& Dam-Johansen, K. (2020). Performance of an automatically controlled wood stove: Thermal efficiency and carbon monoxide emissions. Renewable Energy, 151, 640-647. https://doi.org/10.1016/j.renene.2019.11.057

\section{General rights}

Copyright and moral rights for the publications made accessible in the public portal are retained by the authors and/or other copyright owners and it is a condition of accessing publications that users recognise and abide by the legal requirements associated with these rights.

- Users may download and print one copy of any publication from the public portal for the purpose of private study or research.

- You may not further distribute the material or use it for any profit-making activity or commercial gain

- You may freely distribute the URL identifying the publication in the public portal 


\title{
Performance of an automatically controlled wood stove: Thermal efficiency and carbon monoxide emissions
}

Jytte Boll Illerup ${ }^{1)}$, Brian Brun Hansen ${ }^{1 *}$, Weigang Lin $^{1)}$, Joachim Nickelsen ${ }^{1)}$, Vagn Hvam Pedersen ${ }^{2}$, Bente Eskerod $^{2)}$, Kim Dam-Johansen ${ }^{1)}$

${ }^{1)}$ Department of Chemical and Biochemical Engineering, Technical University of Denmark

Søltofts Plads, Building 229, DK 2800 Lyngby, Denmark

${ }^{2)}$ HWAM A/S, Nydamsvej 53, 8362 Hørning, Denmark

${ }^{*}$ Corresponding author. Tel: +45 45252829. E-mail: bbh@kt.dtu.dk

\begin{abstract}
The development and performance in practice of a commercial automatically controlled wood stove is described. The digital control system controls the three combustion air inlets individually, based on the combustion phase, measured flue gas temperature, measured $\mathrm{O}_{2}$ outlet concentration and desired room temperature. The control system ensured a well-controlled combustion cycle with respect to temperature and oxygen concentration, yielding improved thermal efficiency and minimized carbon monoxide emissions. A minimum in $\mathrm{CO}$ emissions was identified for the oxygen operation range $10-13 \% \mathrm{O}_{2}$. The improved performance has been verified by field tests in 5 private homes, demonstrating more stable and optimal $\mathrm{O}_{2}$ concentrations and temperatures compared to manual operation. This resulted in significant lower $\mathrm{CO}$ concentrations (up to $27 \%$ ) alongside higher thermal efficiency (up to $20 \%$ ) when comparing manually and automatically controlled wood stoves. This new technology has a great potential for improving the stove efficiency/biomass utilisation and reducing the emissions of pollutants at low altitude close to private homes.
\end{abstract}

\section{Keywords $(\max 6)$ :}

wood stove; emission reduction; automatic control; thermal efficiency; carbon monoxide; practical operation

\section{Introduction}

The use of wood stoves is common in European countries and Northern America, providing $\mathrm{CO}_{2}$-neutral energy for residential heating. However, applying old wood stove technologies and poor firing habits often cause operation conditions far from optimal. Thus, wood combustion in small-scale appliances is a major source of carbon monoxide and especially the emission of particulate matter smaller than $2.5 \mu \mathrm{m}$ (PM2.5). In the Nordic countries, small-scale wood combustion appliances is a major emission source of PM $2.5 \mu \mathrm{m}$, for example around $60 \%$ of the total emission in Denmark [1-2]. The high emission level is caused by the challenging conditions: batch firing, small combustion chambers, varying wood moisture content, large wood log sizes, and typically manual control of combustion air flows, which make it difficult to achieve optimal combustion conditions [3]. Previous work has shown that the user behaviors, such as charge mass, ignition procedure, time of recharging, air flow adjustment etc., has utmost importance for the thermal efficiency and emissions [4-5]. In 2016, about $35 \%$ of the woody biomass used for energy and heat in Denmark was combusted in small-scale residential appliances (mainly wood stoves) [6]. In EU almost 65 mill. homes have a room heating appliance and about 1 mill. wood stoves are sold each year [7]. Thus, there is a considerable potential for improving the energy efficiency and reducing the emissions from e.g. the more than 700,000 such small scale appliances in Denmark, and there is an obvious need to provide technical measures that can reduce stove emissions [6]. 
The wood stove combustion process consists of simultaneous heating, drying, pyrolysis, char oxidation and partial oxidation of volatiles at the wood logs and subsequently combustion of released volatiles above the logs. At ideal conditions, those volatiles are oxidized to form $\mathrm{CO}_{2}$ and water as the second step. However, high CO concentration, volatile organic compounds (VOC) and PM emissions are commonly observed because the volatiles are not completely converted. Poor combustion may be indicated by high $\mathrm{CO}$ emissions. It has been shown that $\mathrm{CO}$ to some extent can be used as an indicator for high emissions of VOC and PM [8]. High temperatures, good mixing with adequate oxygen, and a sufficient residence time is needed to ensure oxidation of the volatiles.

Carbon monoxide (CO) is a product formed from partial combustion of volatiles or char. The CO may subsequently be oxidised if oxygen and hydroxide radicals are present with a sufficiently high temperature and residence time. The flow and combustion conditions in household woodstoves may favour $\mathrm{CO}$ emissions, due to both low temperature during the start-up and char burnout stages [9] and low local oxygen concentration in fuel-rich regions of the flames, combined with rapid cooling of part of the flue gas.

In Northern America and Europe, increased attention to pollutant emissions has influenced the design of wood stoves since the 1980s [10-15]. Compared to previous designs, modern Scandinavian stoves are designed to minimize harmful emissions by securing high volatile conversion. The design features often include three air injections (air staging) which ensure optimal temperature and longer residence time combined with sufficient oxygen in the second step of the combustion process [16].

Advice on how to design low-emission stoves has been given by the International Energy Agency [17-18] and SINTEF energy research [19] among others. Modern stoves are designed to minimize carbonaceous particulate emissions [20] and increase energy efficiency/limit flue gas heat loss. But still, the improvement of stove designs to minimize emissions has mainly been performed on an empirical basis by stove manufactures. Even well-designed and well-constructed stoves can occasionally cause high emissions of unburned hydrocarbons, $\mathrm{CO}$ and particulate matters due to the challenging conditions and improper firing habits [21]. Most modern stoves are still designed without automatic control of the combustion process and therefore, with potentially high emissions.

There are various technical solutions for automatically control of the combustion air injection for wood log stoves. Technologies on the market include thermo-mechanical control systems and electronic sensor systems where the temperature is measured in the post combustion chamber. In the present work, a more advanced system is developed, by which a digital control system is able to control the three combustion air inlet valves separately based on simultaneously and continuously measurements of temperatures and oxygen concentrations in the chimney.

The work described in this paper is a part of the project for developing a new type of 'intelligent' automatically controlled wood stoves with superior performance in terms of energy efficiency, reduced emissions (carbon monoxide (CO), volatile organic compound (VOC) and particulate matter (PM)) and high comfort level/low required supervision for the wood stove users. The control system automatically controls the air flows to the combustion chamber for optimization of the combustion conditions. This paper summarizes the development of the control system, describes the prototype tests in laboratory and in a number of private homes, thereby testing the influence of private user practices on gaseous emissions and energy efficiency in comparison to those of old types of stoves.

\section{IHS Woodstove/ Materials and Methods}

The newly developed automatically controlled wood stove is named as IHS (Intelligent Heat System). It is a modern three-step air injection wood stove [6], with a control system comprising measuring devices for the three process parameters (flue gas $\mathrm{O}_{2}$, flue gas temperature and room temperature), and three individually 
controlled air inlet valves.

\subsection{IHS stove outline}

The $4.5 \mathrm{~kW}$ IHS wood stove used, are basically a modern stove with three separately controlled air inlets as illustrated in Figure 1. The three combustion air flows are called primary, secondary and tertiary air: 1) Primary combustion air is led directly through the ash grate in the bottom of the combustion chamber into the layer of gloving charcoal and burning wood logs. The primary combustion air is especially effective for heating and ignition of the wood logs and to establish a good combustion at high temperatures when a new wood charge is loaded into the stove on a layer of glowing charcoal. 2) Secondary combustion air (also called window purge air) is entering into the combustion chamber through an orifice above the window. The secondary air passes the window and enters the lower combustion zone with glowing charcoal, burning wood logs and the volatiles above the wood logs. 3) Tertiary combustion air is entering the combustion chamber through a slit or/and a row of separate holes in the back wall above the grate. The purpose of the tertiary air is to supply oxygen to burn the gaseous combustibles above the wood logs and improve mixing of air and pyrolysis gas before the flue gas leaves the combustion chamber. Other design features include air channels for air preheating, mounting of internal insulation boards that ensure fast heating of the stove, and plates (baffles) that facilitate sufficient mixing and residence time in the combustion zone above the logs.

\subsection{Control strategy}

The three IHS air inlets are controlled by a software program based on the definition of five combustion phases and the measured temperature and $\mathrm{O}_{2}$ in the flue gas outlet of the stove. The combustion phases for a combustion cycle (a charge) are defined as: 0). Start-up of a cold chamber, 1). Ignition of the wood log, 2). Release and combustion of volatiles, 3). Combustion of char, and 4). Burn out and cooling of the chamber. Reloading of wood can take place in all phases. The air box below the combustion chamber contains the three air inlet valves and the software for controlling the valves. The process parameters are the oxygen content and temperature in the flue gas, and the room temperature. The user interface is a remote controller, by which the user can set the desired room temperature. The first version of the control system was optimized to operate at a chimney draft of twelve Pascal.

Figure 2 shows the overall control strategy for the 5 combustion phases with respect to which air inlets are active and what process parameter will be used for controlling air flows. The system is able not only to shift to the next combustion phase but also to change back to the previous phase, depending on the process conditions. When starting from a cold stove in phase 0 the primary air and secondary air are almost fully open to cope with the fast ignition of the fuel (phase 1) and to increase the temperature and thereby minimize the emissions of $\mathrm{CO}, \mathrm{VOC}$ and particulate matters. At the end of phase 1 the tertiary air starts to open to ensure combustion of the volatiles in the freeboard above the bed. In the flame phase (phase 2) where the combustion is so intensive that the temperature increases fast and the primary air is closed to stabilize the temperature and the amount of tertiary air is increased to ensure combustion of the volatiles. In the char combustion phase (phase 3) with almost no volatiles in the freeboard the tertiary air is closed and the combustion rate decrease and the secondary air is reduced. A small amount of primary air is then introduced to prevent decreasing temperature as long time as possible.

The iterative process of developing the algorithms and the air inlet valves were based on a large number of experiments carried out at HWAM and DTU. The purpose was to optimize the combustion process throughout an entire combustion cycle by achieving optimal and constant temperature and $\mathrm{O}_{2}$ concentration in the flue gas, based on theoretical knowledge on the combustion process.

Low emissions of $\mathrm{VOC}, \mathrm{CO}$ and $\mathrm{PM}$ can be achieved by running the stove at optimal temperature and excess air. However, the conditions achieved only by this constraint may decrease the thermal efficiency when too 
high excess air is applied, causing a high energy loss of the flue gas. The challenge is therefore to apply the conditions where both the thermal efficiency (i.e. fraction of heat to the house) is high and the emissions are low. For a given wood stove combustion chamber the optimal excess air (lambda) range can be estimated based on experiments.

\subsection{Methodology}

The IHS stoves were tested in both DTU laboratory and private houses (field tests). A $4.5 \mathrm{~kW}$ research wood stove (Figure 3) was applied to conduct the experiments at DTU. The wood stove was placed on a weighing scale to monitor the weight change of the wood logs and the fuel conversion rate, and it was furthermore equipped with thermocouples at the grate (T2), combustion chamber (T5, T6, T7), above the baffle plate (T8) and in the chimney (T10), and a flue gas sampling and analysis system in which NGA2000 gas analyzers have been used.

All together six new IHS-controlled stoves from Hwam A/S were used for the field tests - one for each test site. Three different stove models were selected and with nominal heat outputs between 4.5 and $6 \mathrm{~kW}$. The five test sites had various installation specifications including house size (116 to $220 \mathrm{~m}^{2}$ ), required heat effect, chimney type, chimney height (from 2 to $14 \mathrm{~m}$ ) and age of the existing stoves (from 0 to 14 years). The results for each test site were compared to test with the previous stove at the same private home. A portable gas analyser (Testo 350) was used to measure the flue gas concentrations of $\mathrm{O}_{2}, \mathrm{CO}_{1}$ and $\mathrm{CO}_{2}$. Furthermore, the indoor and outdoor temperatures were measured together with the moisture content in the wood (beech wood, except site 2 (Baltic spruce)).

The field test was performed in order to evaluate the prototype control systems performance under practical operating conditions and to compare with lab test results on efficiency and CO-emission. The measurements described in this paper have not been performed to obtain optimal combustion conditions, but to study the functionality and combustion process for manually and automatically controlled stoves when used by private wood stove users. The final version of the stove launched on the market was further optimized, among other things based on the experiences gained from these field tests.

\subsection{Data treatment:}

In the data treatment, the method proposed by DS/EN 13240, 2003standard was applied. The CO concentration corrected to $13 \% \mathrm{O}_{2}$ (eq. 4) and the thermal efficiency (eq. 5) illustrated in the following figures was calculated. The $\mathrm{CO}$ emission rate in $\mathrm{mg} / \mathrm{s}$ (eq. 6) was furthermore estimated for selected cases, based on the flow rate at the three IHS air inlets.

$$
\left[C O\left(13 \% O_{2}\right)\right][p p m]=C O \frac{21-13}{21-O_{2}}
$$

$$
\eta=100-\left[100\left[\frac{\mathrm{Q}_{\mathrm{a}}}{\mathrm{H}_{\mathrm{u}}}\right]+100\left[\frac{\mathrm{Q}_{\mathrm{b}}}{\mathrm{H}_{\mathrm{u}}}\right]+0.5\right]
$$

$$
C O[m g / s]=\left(\dot{m}_{p}+m_{s}+m_{t}\right)\left(\frac{\rho_{\mathrm{CO}}}{\rho_{\mathrm{air}}}\right) \mathrm{C}_{\mathrm{CO}}
$$

The correction of the $\mathrm{CO}$ concentration to $13 \% \mathrm{O}_{2}$ (eq. 4) was used to eliminate the influence of varying dilution degrees of the flue gas during combustion. The thermal efficiency (eq. 5) includes the flue gas heat loss $\left(Q_{a}(k J / k g\right.$ wood $\left.)\right)$, partially converted species $\left(Q_{b}(k J / k g\right.$ wood $\left.)\right)$, and un-combusted residuals in the ash $\left(0,5 \%\right.$ assumed). $H_{u}$ is the lower heating value (calculated to 14710 ( $\mathrm{kJ} / \mathrm{kg}$ wood), based on DS/EN 13240. In the present calculations the charge average $\eta$ is calculated based on $\eta$ for each (every 9 seconds) data sampling point (gas concentrations and temperatures). The contribution from the flue gas heat loss ( $\left.Q_{a}\right)$ is generally much higher (app. 5-10 times larger) than the contribution from partially converted species ( $\left.Q_{b}\right)$. 
$\mathrm{CO}$ is the only partially converted species $\left(\mathrm{Q}_{b}\right)$ that has been accounted for because the contribution to the efficiency from other partially converted species such as NMVOC (Non-Methane Volatile Organic Compounds) is much smaller than the CO contribution. The NMVOC emissions from stoves corresponding to the ones used in this work has been reported to be approximately $1 / 12$ of the CO emissions (g/GJ), corresponding to approximately $1 / 3$ on an energy/heating value basis. [9]. Measurements on the automatically controlled stove in DTU pilot hall show the mass ratio (VOC/CO) to be around $1 / 20$. For very poorly fired stoves the calculated thermal efficiency may be overestimated.

The duration of a charge is in DS/EN 13240 based on the weight returning to the starting point/weight before charge, however, instead of installing scales at the 6 sites, a charge was considered stopped by either the addition of new wood or a $120^{\circ} \mathrm{C}$ criteria - for most of the charges this low temperature was not reached before the next charge started. As illustrated in Table 1, for a manually controlled stove, the start of a new charge before the char combustion phase $\left(>200^{\circ} \mathrm{C}\right)$ increase the estimated average thermal efficiency and decrease the $\mathrm{CO}$ concentration. But the specific location of a cut-off temperature that include the char combustion phase $\left(120^{\circ} \mathrm{C}\right.$ and $\left.150^{\circ} \mathrm{C}\right)$ has a limited influence on the data set, No requirement concerning charge size and minimum duration was used.

At each test site continuous measurements of $\mathrm{O}_{2}, \mathrm{CO}_{2}, \mathrm{CO}$ and flue gas temperature (only at stack sampling location) were conducted with both the existing stove and the new HWAM IHS stove. For the same wood stove users, the measuring period for each stove was one week. In all the tested, IHS wood stove models were equipped with a prototype of the automatic control system.

The person using the wood stove was instructed to not change firing habits - i.e. continue using the same kind of wood and firing in the same way. Furthermore, the stove user was asked to use uniform wood types like hardwood or softwood, weight the wood before each firing period, and to note the weight, water content and time in a log book.

\section{Results}

\subsection{First prototype tests - optimization of control system}

The first prototype experiments were aimed at establishing optimal control system set points for oxygen concentration and temperature. Figure 4 shows the $\mathrm{CO}$ concentration as a function of the $\mathrm{O}_{2}$ concentration for tests with wood loads from 1.5 to $3.0 \mathrm{~kg}$. The results show an optimal oxygen concentration around 10$13 \%$ in the flue gas. Figure $5 \mathrm{a}$, show that the highest $\mathrm{CO}$ concentration appears in the beginning of the combustion cycle ( $2 \mathrm{~kg}$ charge) soon after the ignition of the wood takes place (0-5 $\mathrm{min}$ ), and during the char burnout period with decreasing temperatures ( 55 min onwards). The measured temperatures in the top of the combustion chamber (T7/T8) and in the chimney (T10) show the same overall trend, with a 100 ${ }^{\circ} \mathrm{C}$ temperature difference during burnout and a more stable signal for $\mathrm{T} 10$. Figure $5 \mathrm{~b}$ also shows the mass flux of $\mathrm{CO}$ emitted $(\mathrm{mg} / \mathrm{s})$. Because the control system automatically reduces the combustion air during the char combustion phase, the total amount of $\mathrm{CO}$ mass flux emitted decreases, even though, the $\mathrm{CO}$ concentration increases. But still, a considerable amount of CO may be emitted at the end of a combustion cycle. The results were used to further optimize the temperature set-point to decrease the $\mathrm{CO}$ emissions before the field test.

Figure 6 shows the CO concentration for the char combustion phase (phase 3 ) in three subsequent charges as a function of temperatures T8 (at the top of the combustion chamber) and T10 (in the lower part of the chimney). For T10, a steep increasing $\mathrm{CO}$ concentration is seen in a narrow window starting from $350{ }^{\circ} \mathrm{C}$ where the $\mathrm{CO}$ concentration is close to zero, and down to $250^{\circ} \mathrm{C}$ were the $\mathrm{CO}$ concentration approaches $5000 \mathrm{ppm}$ (For T8 the ranges are $550-350^{\circ} \mathrm{C}$ ). These results establish minimal temperature process parameter set-points to control $\mathrm{CO}$ emissions. Furthermore, the experiments showed that $\mathrm{T} 10$ was the most stable temperature signal (as seen in Figure 5) and therefore being the best control parameter to be 
used; a set-point of $350^{\circ} \mathrm{C}$ for T10 was therefore used for the field tests. For the flame phase (phase 2) the CO levels were generally low at the high operating temperature, but $>1000 \mathrm{ppm}$ CO was observed a few times, indicating that other factors than the temperature influences the CO-emission - such as lack of oxygen locally in the flame resulting in formation of $\mathrm{CO}$ due to the very intensive combustion process.

The CO concentrations in figure 6 can also be qualitatively compared to a kinetic model for fuel-lean, moist, post-flame $\mathrm{CO}$ oxidation in a isothermal plug flow reactor by Glarborg et al. [22] at realistic woodstove conditions ( $10000 \mathrm{ppm} \mathrm{CO}, 12 \% \mathrm{O}_{2}, 1 \% \mathrm{H}_{2} \mathrm{O}$ and $8 \mathrm{~s}$ residence time) for the char combustion phase. In Figure 6 it is seen that the isothermal kinetic model predicts that the $\mathrm{CO}$ oxidation stops around $700{ }^{\circ} \mathrm{C}$, causing increased $\mathrm{CO}$ emissions. The T10 and T8 data display a similar steep increase in CO concentration, when the temperature decreases to $350-550{ }^{\circ} \mathrm{C}$. A direct comparison is not possible due to the nonisothermal conditions in the stove chamber. The T10 and T8 temperatures are measured in the top of the combustion chamber and in the chimney where the temperatures are lower than just above the char bed, here the temperatures are typically in the range $700-1000^{\circ} \mathrm{C}$; thus in better agreement with the model.

These initial tests contributed to improvement of the control system regarding: 1) Optimization of the parameters in the control unit to avoid large fluctuations in the flame phase/phase two, 2) Optimization of the ratio between the flow rate of secondary and tertiary air in phase two, 3) Demonstration of a more stable and clean combustion when using the chimney temperature $(\mathrm{T} 10)$ of $350^{\circ} \mathrm{C}$ and an $\mathrm{O}_{2}$ concentration around $10.5 \%$.

\subsection{Field tests}

Before introducing this new control system to the market, it was decided to test the prototype of the control system in field tests on a number of wood stoves operated by ordinary wood stove owners. The main focus is on the results from existing manually fired wood stoves compared to the results from the new IHS stove to investigate the influence of the combustion conditions and private stove users' practices on the emissions and efficiency.

A typical IHS combustion cycle consist of a short ignition period (phase 1), followed by a stabilization of temperature and $\mathrm{O}_{2}$ concentration at constant and optimal set point values in phase 2 and the values remain constant for most of the combustion cycle. The $\mathrm{CO}$ concentration increases at the very end of the combustion cycle, when the temperature starts to drop during the char-burn-out phase (phase 3 ). This result in an improved efficiency when using the IHS-stove at all sites, also lower CO emissions were measured for most of the sites as shown in Table 2.

Figure 7 and 8 show gas concentrations, energy efficiency and temperatures for two selected cases for manually and automatically controlled stoves. These illustrate two typical main cases of non-optimal firing of manually controlled stoves due to firing practice:

1) Too high excess air during the entire combustion cycle (Figure 7a)

2) Too little air during the flame phase and too much air during the char combustion phase (Figure 8a)

The user in case 1) focused on obtaining a clean combustion by burning at high temperatures, and measurements also show high temperature and $\mathrm{O}_{2}$ concentration in the combustion chamber. Figure $7 \mathrm{~b}$ show the almost constant temperatures and $\mathrm{O}_{2}$ concentrations obtained with the automatic control of the combustion air. The $\mathrm{O}_{2}$ concentrations varied from $9 \%$ to $12 \%$ and the temperature from $230^{\circ} \mathrm{C}$ to $290^{\circ} \mathrm{C}$ during the flame phase. Because of the low heat output of the remaining char in charge 4 , the temperature gradually drops and the $\mathrm{CO}$ concentration starts to increase at the end of the char combustion phase. The tests conducted at this site showed that the efficiency increased from about $59 \%$ to $79 \%$ and the average CO concentration was reduced by approx. $16 \%$ when the wood stove user switched from a modern manually controlled stove to an automatic IHS stove. The increase in energy efficiency was predominantly 
(app $98 \%$ ) obtained by controlling the flue gas heat loss (temperature and flow) and only to a lesser extent (2\%) due to a reduced slip of unburnt CO.

The length of the char combustion phase is of high importance for the calculated average CO concentration - a long char combustion time at lower temperatures would increase the average CO concentration. The significant influence of the control system on the efficiency (30-40\% points), and the CO concentration only in the char combustion phase is illustrated in table 3 where selected combustion cycles for the IHS and the existing stove (figure $8 a$ and $b$ ) are compared for reloading in the flame phase ( $T_{\text {cut }} \approx 230$ ) and a burnout including the char combustion phase $\left(T_{\text {cut }} \approx 160\right)$.

The user in case 2) was good at firing and from the direct observations it seemed that a clean combustion was obtained. However, from the measurements (Figure 8a) high concentrations of $\mathrm{CO}$ were seen in the flame phase. When the same user applied an automatic IHS controlled stove (Figure 8b), very constant flue gas temperatures, $\mathrm{O}_{2}$ and $\mathrm{CO}$ concentrations were obtained. Especially in the flame combustion phase, a significant reduction of the $\mathrm{CO}$ concentration was seen. The efficiency for this site increased from 76 to 80 $\%$ and the $\mathrm{CO}$ emission was reduced by around $27 \%$. In this case both control of the flue gas heat loss (app $30 \%$ ) and a reduced slip of unburnt CO (app $70 \%$ ) contributed to the $4 \%$ increase in energy efficiency, illustrating the importance of both parameters for further improvement of modern high efficiency stoves.

Some main observations from the other test sites in Table 2 are given below.

- At site 3 a chimney fan resulted in a high chimney draft and thereby high excess air for both the existing stove and the IHS stove - a charge average $\mathrm{O}_{2}$ concentration in the range 15-17\%. The control system is optimized for $12 \mathrm{~Pa}$ and it could not compensate for the high draft in this chimney. Therefore only a small improvement in the efficiency (1-2\%) and CO emissions (600 ppm lower) was seen for this site.

- At site 4 a different wood type (Baltic pine) was used and increasing soot formation and blackening of the stove front window was observed - the problem was not observed when beech wood was used for a few extra test charges. Still a $4 \%$ improvement in thermal efficiency was obtained as well as app $800 \mathrm{ppm}$ lower CO emissions.

- The user at site 5 generally used wood with a high content of water (18-25\%) resulting in delayed or failed ignition and consequently very high emissions of smoke and CO (7000-9000 ppm). In this case higher $\mathrm{CO}$ emission from the IHS stove was also seen due to the wet wood logs used, but the efficiency improved from 66 to $73 \%$, due to a better control of the flue gas heat loss.

\section{Conclusions}

A new automatically controlled wood stove has been developed. The automatic control system ensures optimal temperatures $\left(350^{\circ} \mathrm{C}\right.$ measured in the chimney) and oxygen concentration (10-13\%) throughout the combustion cycles with minimal user involvement, making it very robust to different ways of operating the stove. The measurement and optimization of the oxygen concentration avoid both too high excess air (low thermal efficiency) and under-stoichiometric combustion (high emissions of $\mathrm{CO}$ and unburnt gaseous combustibles). $\mathrm{CO}$ emissions mainly took place in phase 3 (char combustion) as the oxidation to $\mathrm{CO}_{2}$ stops when the bed temperature drops below a critical level (app $700^{\circ} \mathrm{C}$ ).

The field tests showed significantly reduced emissions (500-1000 ppm lower CO) and high efficiency (2-20\% absolute increase) for the automatically controlled stoves compared to manually controlled stoves. The automatic control of process conditions throughout the combustion cycles, made it very robust to different ways of operating the stove. This resulted in similar high efficiencies and low $\mathrm{CO}$ concentrations when used by common wood stove users as when the stove was tested at standardized conditions during research tests. 
These tests clearly showed that other parameters than the design of the wood stove influences the combustion process and thereby the efficiency and the emission of harmful compounds. In prioritized order the most important factors for the present tests are: 1) the firing practice, 2) the water content in the wood logs, 3) the chimney draft and 4) the wood type. Furthermore, the results show that in most cases the IHS controlled stove is able to improve the efficiency and reduces the CO-emissions compared to the manually controlled stove by eliminating poor firing practice.

\section{Acknowledgement}

356 This work was supported by The Danish Energy Agency - Energy Technology Development and 


\section{REFERENCES}

[1] Nielsen, O-K., Plejdrup, M.S., Winther, M., Mikkelsen, M.H., Nielsen, M., Gyldenkærne, S., Fauser, P., Albrektsen, R., Hjelgaard, K.H., Bruun, H.G., Thomsen, M. 2017. Annual Danish Informative Inventory Report to UNECE. Emission inventories from the base year of the protocols to year 2015. Aarhus University, DCE Danish Centre for Environment and Energy, . Scientific Report No. 222 http://dce2.au.dk/pub/SR222.pdf

[2] Illerup, J.B.,Sternhufvud, C., Karvosenoja, N., Kindbom, K., Lükewille, A., Johansson, D., and Jensen, M., Particulate matter emissions and abatement options in residential wood burning in the Nordic countries. Department of policy analysis, 2004.

[3] Heringa, M.F., DeCarlo, P.F., Chirico, R., Lauber, A., Doberer, A., Good, J., Nussbaumer, T., Keller, A., Burtscher, H., Richard, A., Miljevic, B., Prevot, A.S., Baltensperger, U.. Time-resolved characterization of primary emissions from residential wood combustion appliances. Environ Sci Technol. 2012

[4] Schön, C.; Hartmann, H. 2012: Log Wood Combustion in Stoves. Influence on Emissions and Efficiency. Proceedings of the International Conference. 20th European Biomass Conference and Exhibition. Milano, Italy, 18-22 June. Florence, Italy: ETA-Florence Renewable Energies, WIP-Renewable Energies, S. 1293-1298, ISBN 978-88-89407-54-7

[5] Reichert, G.; Schmidl, C.; Haslinger, W.; Schwabl, M.; Moser, W.; Aigenbauer, S.; Wöhler, M.; Hochenauer, C. Investigation of user behaviour and assessment of typical operation mode for different types of firewood room heating applications in Austria. Renewable Energy 2016, 93, 245-254.

[6] Illerup, J. B.; Henriksen, T. C.; Lundhede, T.; Breugel, C. van; Jensen, N. Z. (2007): Brændeovne og små kedler - partikelemissioner og reduktionstiltag (Woodburning stoves and small boilers - particle emissions and reduction measures). Miljøprojekt Nr. 1164, Miljøstyrelsen. In Danish. Available at: http://www2.mst.dk/Udgiv/publikationer/2007/978-87-7052-451-3/pdf/978-87-7052-452-0.pdf

[7] Kienle, F. (2015), HKI, Germany, Market development and perspectives, Expert workshop on Highly Efficient and Clean Wood Log Stoves, 29 October 2015.

[8] Olsson, M.; Kjallstrand, J. Low emissions from wood burning in an ecolabelled residential boiler. Atmos. Environ. 2006, 40 (6), 1148-1158.

[9] Brunner, T., Biedermann, F., Obernberger, I. Primary measures for low-dust combustion - relevant finding Internationaler Task-Workshop zum Thema „Aerosols from small-scale biomass combustion plants“: 27. Jänner 2011 in Graz (Organisation und wissenschaftliche Leitung: Österreich).

[10] Koppejan, J. and Van Loo, S., The handbook of biomass combustion and co-firing. 2012: Routledge.

[11] Houck, J.E., Tiegs, P.E., and McCrillis, R.C., Residential Wood Combustion Technology Review Volume 1. Technical Report. Prepared for the United States Environmental Protection Agency, Office of Research and Development, 1998.

[12] Musil-Schläffer, B., McCarry, A., Schmidl, C., and Haslinger, W., European wood-heating technology survey: an overview of combustion principles and the energy and emissions performance characteristics of commercially available systems in Austria, Germany, Denmark, Norway, and Sweden. Final report prepared for the New York State Energy Research and Development Authority (NYSERDA), 2010.

[13] Pettersson, E., Boman, C., Westerholm, R., Bostrom, D., and Nordin, A., Stove Performance and Emission 
Characteristics in Residential Wood Log and Pellet Combustion, Part 2: Wood Stove. Energy \& Fuels, 2011. 25: 315-323.

[14] Johansson, L.S., Leckner, B., Gustavsson, L., Cooper, D., Tullin, C., and Potter, A., Emission characteristics of modern and old-type residential boilers fired with wood logs and wood pellets. Atmospheric Environment, 2004. 38(25): 4183-4195.

[15] Nussbaumer, T., Combustion and co-combustion of biomass: fundamentals, technologies, and primary measures for emission reduction. Energy \& fuels, 2003. 17(6): 1510-1521.

[16] Nussbaumer, T. Combustion and co-combustion of biomass: fundamentals, technologies, and primary measures for emission reduction. Energy Fuels_2003, 17 (6), 1510-1521.

[17] Virén, A., Lamberg, H., tissari, J., Sippula, O., Jokiniemi, J., Obernberger, I., Biedermann, F., Brunner, T., Hartmann, H., Schön, C., Turowski, P.. ERA-NET Bioenergy. Project FutureBioTec, "Future low emission biomass combustion systems", Guidelines for low emission chimney stove design. University of Eastern Finland, 2012.

[8] Obernberger I., Brunner, T.; 2015: Guidelines and relevant issues for stove development. Workshop on Highly Efficient and biomass

Clean Wood Log Stoves within IEA Bioenergy Conference, October 2015, Berlin, Germany; http://www.ieabcc.nl/workshops/task32 2015 Berlin/index.html

[19] Skreiberg, $\varnothing$., Seljeskog, M.. Performance history and further improvement potential for wood stoves. Chemical Engineering Transactions, 2018, 65. 199-204

[20] Schmidl, C., Luisser, M., Padouvas, E., Lasselsberger, L., Rzaca, M., Ramirez-Santa Cruz, C., Handler, M., Peng, G., Bauer, H., and Puxbaum, H., Particulate and gaseous emissions from manually and automatically fired small scale combustion systems. Atmospheric Environment, 2011. 45(39): 7443-7454.

[21] Pettersson, Esbjørn, Boman, Christoffer, Westerholm, Roger, Boström, Dan, Nordin, Anders, 2011, Stove Performance and Emission Characteristics in Residential Wood Log and Pellet Combustion, Part 2: Wood Stove, Energy \& Fuels, 2011, 25 (1), 315-323.

[22] Glarborg, P.; Kubel, D.; Kristensen, P.G.; Hanse, J. Interactions of CO, $\mathrm{NO}_{x}$ and $\mathrm{H}_{2} \mathrm{O}$ under Post-Flame Conditions. Combustion Science and Technology, 1995, 110-111, 461-485. 
454

455

456

457

458

459

Table 1. The influence of the cut-off temperature on thermal efficiency and average CO concentration for a site 1 old stove charge with a long burnout.

\begin{tabular}{lrrrr}
\hline Cut-off temperature, ${ }^{\circ} \mathrm{C}$ & 120 & 150 & 200 & 300 \\
Estimated thermal efficiency & 38 & 41 & 46 & 59 \\
CO concentration at $13 \% \mathrm{O}_{2}$ (ppm) & 4888 & 4934 & 4860 & 2153 \\
\hline
\end{tabular}

Table 2. Overview of test sites - charges, average CO concentration and thermal efficiency

\begin{tabular}{ccccccc}
\hline & \multicolumn{3}{c}{ Old stove } & \multicolumn{3}{c}{ New stove } \\
Case & Charges & Co ppm $\left(13 \% \mathrm{O}_{2}\right)$ & Efficiency & Charges & CO ppm $\left(13 \% \mathrm{O}_{2}\right)$ & Efficiency \\
\hline 1 & 33 & 3100 & $59.4 \%$ & 40 & 2590 & $79.2 \%$ \\
2 & 6 & 3700 & $76.5 \%$ & 11 & 2710 & $80.0 \%$ \\
3 & 30 & 5170 & $67.3 \%$ & 26 & 4520 & $68.9 \%$ \\
4 & 46 & 5480 & $68.8 \%$ & 33 & 4720 & $73.2 \%$ \\
5 & 26 & 6590 & $66.0 \%$ & 19 & 9450 & $73.4 \%$ \\
\hline
\end{tabular}

Table 3. Influence of the control system in the char combustion phase

\begin{tabular}{lrrr}
\hline Stove type & Cut-off temp. $\left({ }^{\circ} \mathrm{C}\right)$ & $\mathrm{CO} \mathrm{ppm}\left(13 \% \mathrm{O}_{2}\right)$ & Efficiency \\
\hline IHS stove & 237 & 1211 & 80 \\
IHS stove & 161 & 3163 & 79 \\
Existing stove & 223 & 3856 & 51 \\
Existing stove & 161 & 4945 & 42 \\
\hline
\end{tabular}

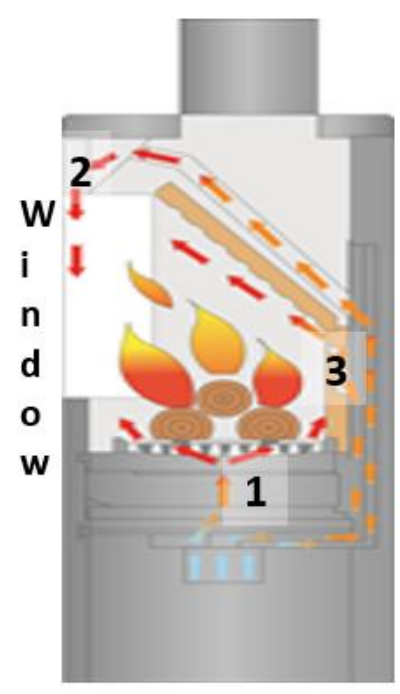

Figure 1. Illustration of a modern wood stove showing the combustion chamber and the three air inlets. 1) Primary air, 2) Secondary air, 3) Tertiary air 
467

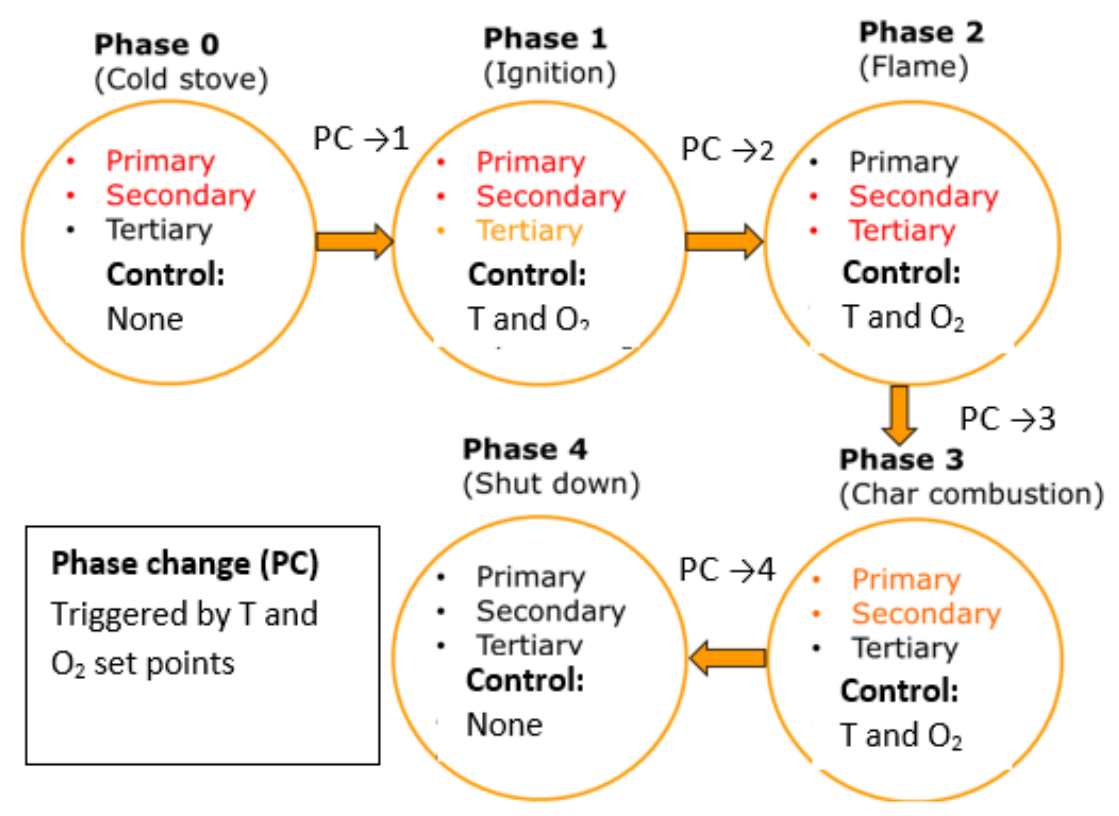

Figure 2. Overall concept of the software. The color of the type of combustion air indicates the amount of air introduced. Red: high amount, Orange: small amount, Black: closed.
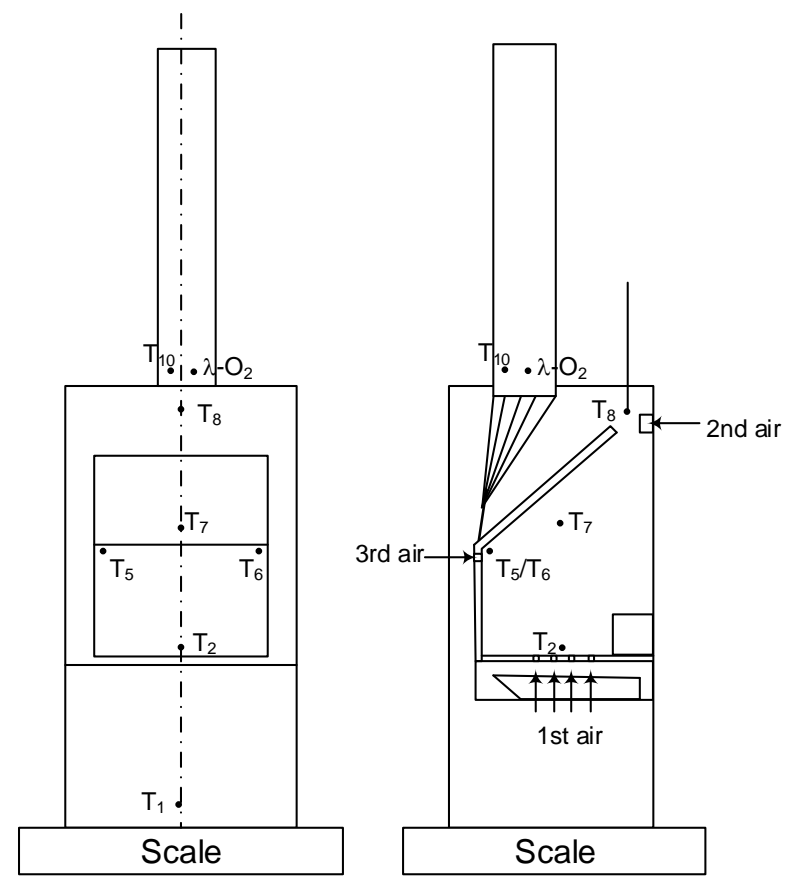

Figure 3. Research wood stove and location of thermocouples. 


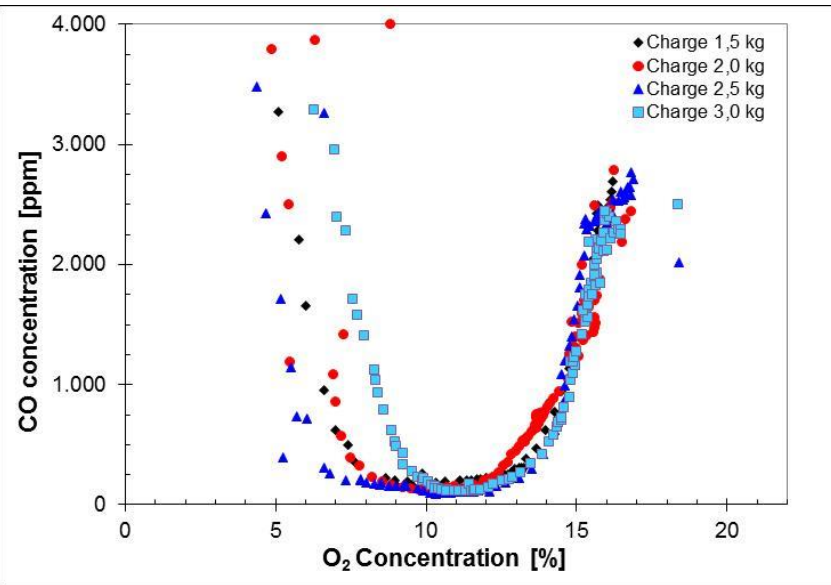

Figure 4. $\mathrm{CO}$ concentration as a function of $\mathrm{O}_{2}$ concentration.
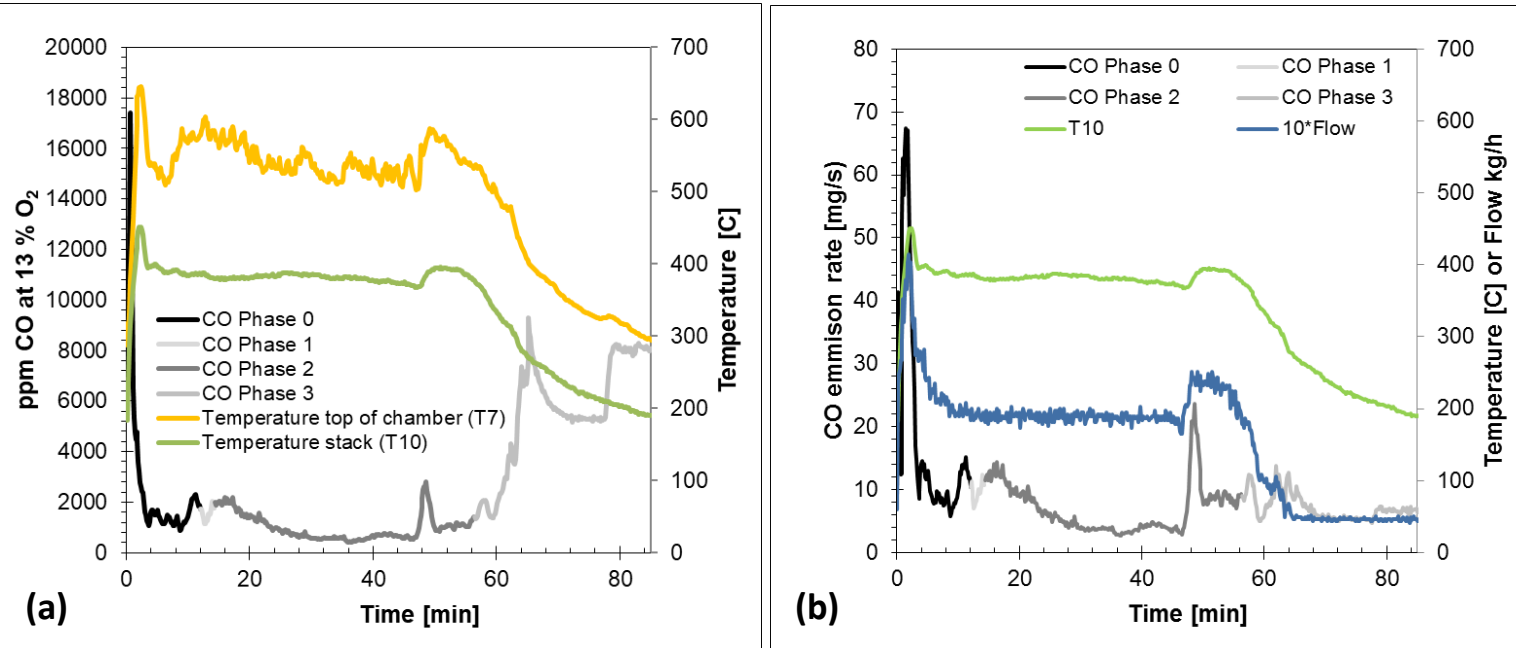

Figure 5. Examples of $\mathrm{CO}$ concentration, $\mathrm{CO}$ emissions rate, air flow and temperature trends for one 481 combustion cycle for a prototype of the control system. a) $\mathrm{CO}$ in ppm, b) $\mathrm{CO}$ in $\mathrm{g} / \mathrm{sec}$. 


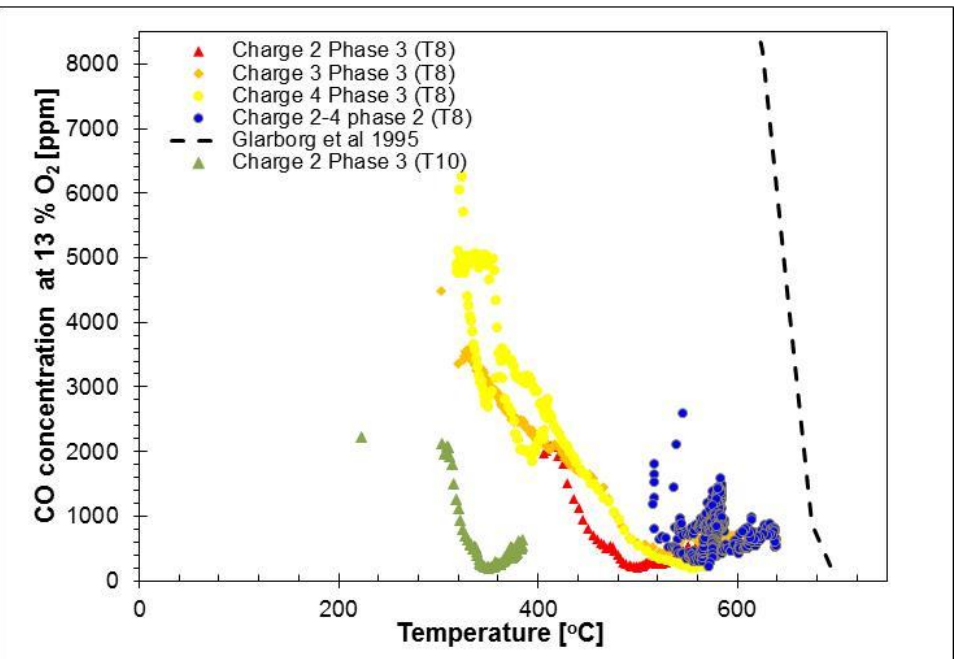

Figure 6. Measured CO concentration as a function of the temperature at the top of the combustion an isothermal post-flame kinetic plug-flow model at the process conditions: $0.1 \% \mathrm{CO}, 12 \% \mathrm{O}_{2}, 1 \% \mathrm{H}_{2} \mathrm{O}$ and $\tau=8 \mathrm{~s}$.
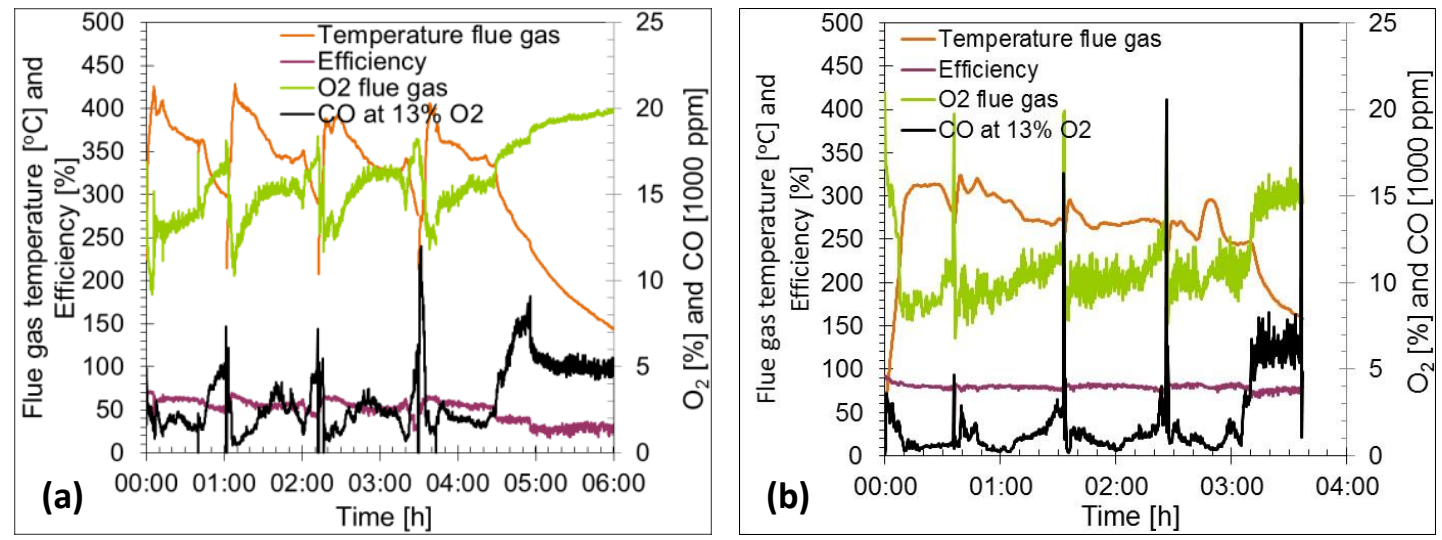

Figure 7. Case 1: Field test measurement conducted with a privately operated wood stove with the user applying a manually controlled stove a) and an automatic IHS stove b) (four combustion cycles).

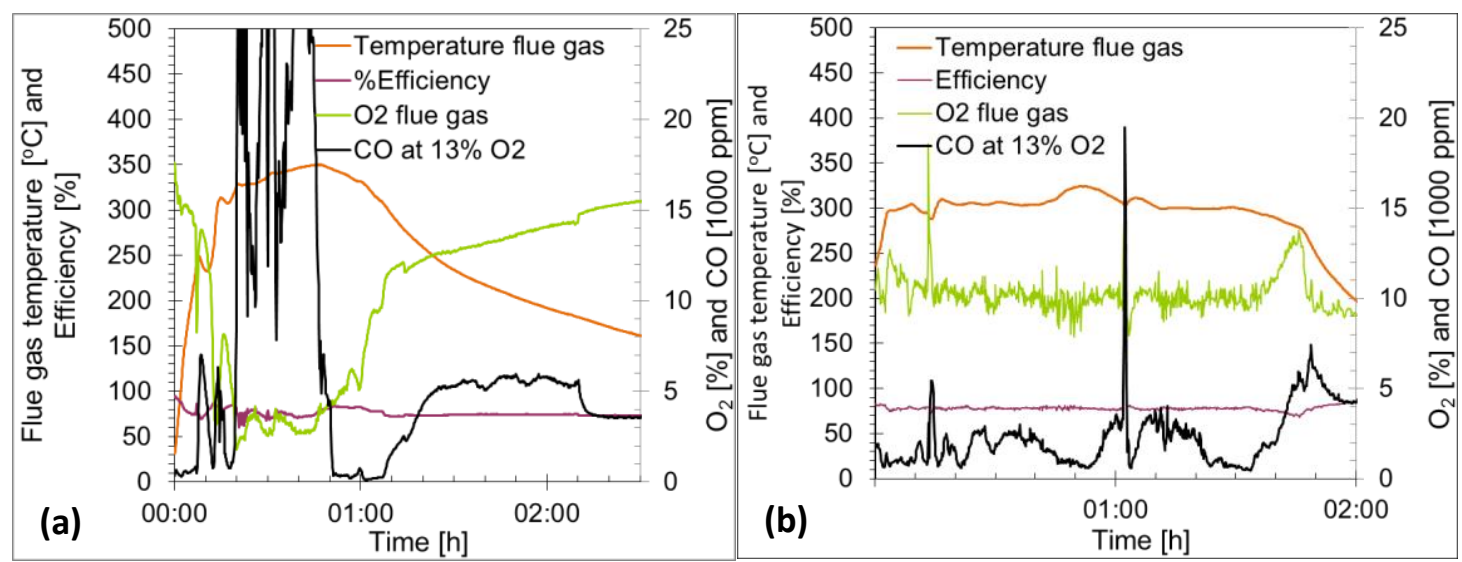

495 Figure 8. Case 2: Field test measurement conducted with a privately operated wood stove with the user 496 applying a manually controlled stove a) and an automatic IHS stove b) (two combustion cycles) 